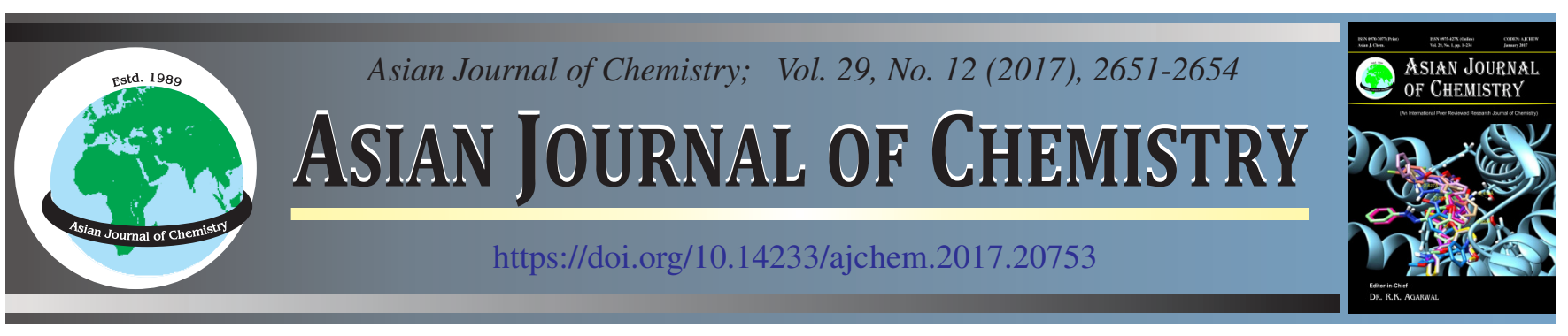

\title{
Luminescence and Electrochemical Properties of Organostannoxane Coordination Polymer Based on Ferrocenyl-2-Cyano Carboxylate Ligand
}

\author{
Ezhumalai David and Nallasamy Palanisami
}

Department of Chemistry, School of Advanced Sciences, VIT University, Vellore-632 014, India

*Corresponding author: E-mail: palanisami.n@vit.ac.in

Organostannoxane-based multiredox assemblies containing ferrocenyl peripheries have been readily synthesized by a simple one-pot synthesis, with quantitative yields. The reaction of triorganotin oxides, $(n \mathrm{BuSn})_{2} \mathrm{O}$ with 2-cyano-3-ferrocenyl acrylic acid leads to the formation of $\left[\left(n \mathrm{Bu}_{3} \mathrm{SnOC}(\mathrm{O}) \mathrm{CNCHFc}\right)_{n}\right]$ polymeric structure. FT-IR, NMR, UV-Vis and emission spectroscopic techniques were performed for the characterization of $\left[\left(n \mathrm{Bu}_{3} \mathrm{SnOC}(\mathrm{O}) \mathrm{CNCHFc}\right)_{n}\right]\left(\mathrm{Fc}=\eta^{5} \mathrm{C}_{5} \mathrm{H}_{4}-\mathrm{Fe}-\eta^{5} \mathrm{C}_{5} \mathrm{H}_{4}\right)$ polymeric structure. Electrochemical studies on these hybrid organotin/ferrocene systems reveal that most of them exhibit a single quasi-reversible oxidation peak.

Keywords: Ferrocene, Organostannoxane, Electrochemistry.

\section{INTRODUCTION}

Organometallic polymers have been attracting considerable attention in recent years with a view to generating new materials with interesting electrochemical, electronic and magnetic properties [1,2]. In particular, the ferrocene appended stannoxane frameworks are interest due to electrochemically inertness and do not interfere with the electrochemical properties of the peripheral ferrocene moiety [3-5]. Also, these molecules possess good electric, optical and magnetic properties [6-8]. On the other hand, cyanoacrylic acid based molecules used as a dyes in dye-sensitized solar cells [9]. In general, organotin compounds are traditionally synthesized by the use of high boiling solvents under reflux conditions and the structural diversity is depends on the reaction conditions $[10,11]$. In this study, we used simple one pot reaction between organotin $\left(n \mathrm{Bu}_{3} \mathrm{Sn}\right)_{2} \mathrm{O}$ precursor and 2-cyano-3-ferrocenyl acrylic acid which leads polymeric compound. The spectroscopic and electrochemical were investigated.

\section{EXPERIMENTAL}

All the starting materials and the products were found to be stable towards moisture and air. Solvents were freshly distilled over suitable drying agents. $\left(n \mathrm{Bu}_{3} \mathrm{Sn}\right)_{2} \mathrm{O}$ is commercially available and it is purchased from Alfa-Aesar. $\mathrm{FcCH}(\mathrm{CN}) \mathrm{COOH}$ was prepared based on literature procedure [9]. UV-visible spectra were obtained on a JASCO-V-670 spectrophotometer and emission spectra were obtained on a fluorescence spectrophotometer (HITACHI F7000). Infrared spectra were obtained using $\mathrm{KBr}$ disks on a SHIMADZU $\left(4000-400 \mathrm{~cm}^{-1}\right)$ FT-IR spectrometer, ${ }^{1} \mathrm{H}$ and ${ }^{13} \mathrm{C}$ NMR spectra were recorded using a BRUKER-FTNMR-400 MHZ spectrometer $\mathrm{CDCl}_{3}$ solvent and tetramethylsilane as an internal standard. The electrochemical analysis was done by $\mathrm{CH}$-instruments (CHI760E). In all electrochemical measurements, $0.1 \mathrm{MBu}_{4} \mathrm{NClO}_{4}$ (TBAP) was used as a supporting electrolyte. The working electrode was a glassy carbon and the counter electrode was a platinum wire. The operating reference electrode was a non-aqueous $\mathrm{Ag} / \mathrm{AgCl}$.

Synthesis of $\left[\left(n \mathrm{Bu}_{3} \mathrm{SnOC}(\mathrm{O}) \mathrm{CNCHFc}\right)_{n}\right]$ : A stoichiometric mixture of $\left(n \mathrm{Bu}_{3} \mathrm{Sn}\right)_{2} \mathrm{O}(0.6 \mathrm{mmol})$ and 2-cyano-3-ferrocenyl acrylic acid $(1.2 \mathrm{mmol})$ were dissolved in dry toluene $(50 \mathrm{~mL})$ and the reaction mixture was heated to reflux and azeotropic removal of water was achieved via as Dean-Stark apparatus. After $6 \mathrm{~h}$, the reaction mixture was filtered and evaporated to dryness. The corresponding residue was washed with petroleum ether and dried in air to give the polymeric compound (Scheme-I). Yield: $670 \mathrm{mg}(96.5 \%)$, m.p. $188{ }^{\circ} \mathrm{C}$; ${ }^{1} \mathrm{H}$ NMR $(400 \mathrm{MHz}$, $\left.\mathrm{CDCl}_{3}\right) \delta=\left(\mathrm{t}, J=7.42 \mathrm{~Hz}, 9 \mathrm{H}\right.$; butyl $\left.\mathrm{CH}_{3}\right), 2.10$ (m, 18H; butyl $\mathrm{CH}_{2}$ ), 4.16 (s, 5H; ferrocenyl), 4.60, 2H; ferrocenyl), $4.91 \mathrm{ppm}$ (t, $J=1.95 \mathrm{~Hz}, 2 \mathrm{H}$; ferrocenyl); $8.09(1 \mathrm{H}$; $-\mathrm{CH}-\mathrm{C}=\mathrm{C} \equiv \mathrm{N}) \mathrm{ppm}$. ${ }^{13} \mathrm{C}$ NMR data $\left(400 \mathrm{MHz}, \mathrm{CDCl}_{3}\right): \delta=117.5(\mathrm{C} \equiv \mathrm{N}), 206.06$ $(\mathrm{C}=\mathrm{O}), 129.40,130.44,136.94,158.88,168.45,98.52,74.43$, 73.75, 71.65, 70.50, 30.97 ppm. UV-visible $\left(\mathrm{CH}_{3} \mathrm{CN}, \mathrm{nm}\right): 264$, 314, 380, 515. Fluorescence: $\left(\lambda_{\mathrm{ex}}=314 \mathrm{~nm}, \mathrm{CH}_{3} \mathrm{CN}\right): 412 \mathrm{~nm}$. 


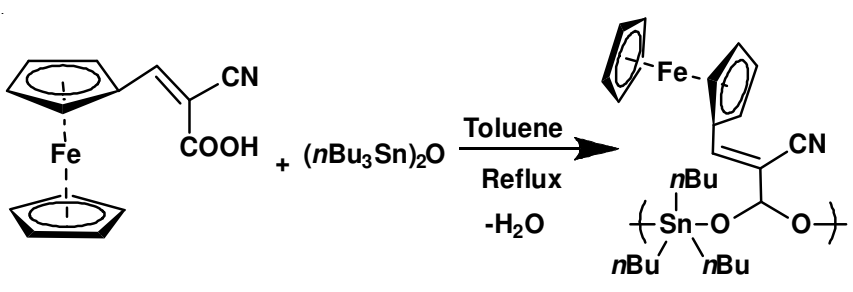

Scheme-I: Synthesis of ferrocenylorganostannoxane

\section{RESULTS AND DISCUSSION}

The polymeric compound $\left[\left(n \mathrm{Bu}_{3} \mathrm{SnOC}(\mathrm{O}) \mathrm{CNCHFc}\right)_{\mathrm{n}}\right]$ was obtained in an analytically pure state was characterized by FT-IR, FT-NMR, UV-visible absorption and emission spectroscopy. The ${ }^{1} \mathrm{H}$ and ${ }^{13} \mathrm{C}$ NMR spectra of ferrocenylorganostannoxane is displayed in Figs. 1 and 2. The singlet from $4.16 \mathrm{ppm}$ is due to cyclopentadienyl ring protons of ferrocene. The singlet at 4.60 and $4.91 \mathrm{ppm}$ are assigned to substituted cyclopentadienyl ring protons. The singlet at $8.09 \mathrm{ppm}$ is due to the $(\mathrm{N} \equiv \mathrm{C}=\mathrm{CH})$ protons [12]. The two doublets at $7.42 \mathrm{ppm}$ were observed due to the aliphatic methyl protons. The singlet at $8.58 \mathrm{ppm}$ is due to aromatic proton. The ${ }^{1} \mathrm{HNMR}$ spectrum of ferrocenylorganostannoxane compared in litreature [13]. The ${ }^{13} \mathrm{C}$ NMR spectrum of the compound showed at $70.5 \mathrm{ppm}$ is corresponding to the unsubstituted carbon of cyclopentadienyl ring in ferrocene moiety whereas substituted cyclopentadienyl ring carbon appears at 73.7 and $76.3 \mathrm{ppm}$, respectively. Aliphatic $\mathrm{CH}_{3}$ appear $30.9 \mathrm{ppm}$ and corresponding $n$-butyl $\left(\mathrm{CH}_{2}-\mathrm{CH}_{2}-\mathrm{CH}\right.$-) carbon appear at 128-137 ppm due to bulky organostannoxane.The nitrile group of $(\mathrm{C} \equiv \mathrm{N})$ appears at $117.5 \mathrm{ppm}$ and carbonyl group appears at $207.0 \mathrm{ppm}$.

The IR spectra of compound shows strong peaks at 1743 $\mathrm{cm}^{-1}$ which is attributable to the $v_{\text {asym }}(\mathrm{COO})^{-}$stretch. The corresponding $\mathrm{v}_{\mathrm{sym}}(\mathrm{COO})^{-}$stretch is found $1368 \mathrm{~cm}^{-1}$. In general, $\mathrm{v}_{\text {asym }}(\mathrm{COO})^{-}$for esters are lower than for free carboxylic acids; correspondingly the $\mathrm{v}_{\mathrm{sym}}(\mathrm{COO})^{-}$for esters moves up in comparison to carboxylic acids [14]. The $\mathrm{C}-\mathrm{H}$ bending of ferrocene ring appeared at $806 \mathrm{~cm}^{-1}$ and band due to $\mathrm{Cp}-\mathrm{Fe}-\mathrm{Cp}$ stretching vibration of ferrocenyl moiety occurs in the range $476-518 \mathrm{~cm}^{-1}$ (Fig. 3).

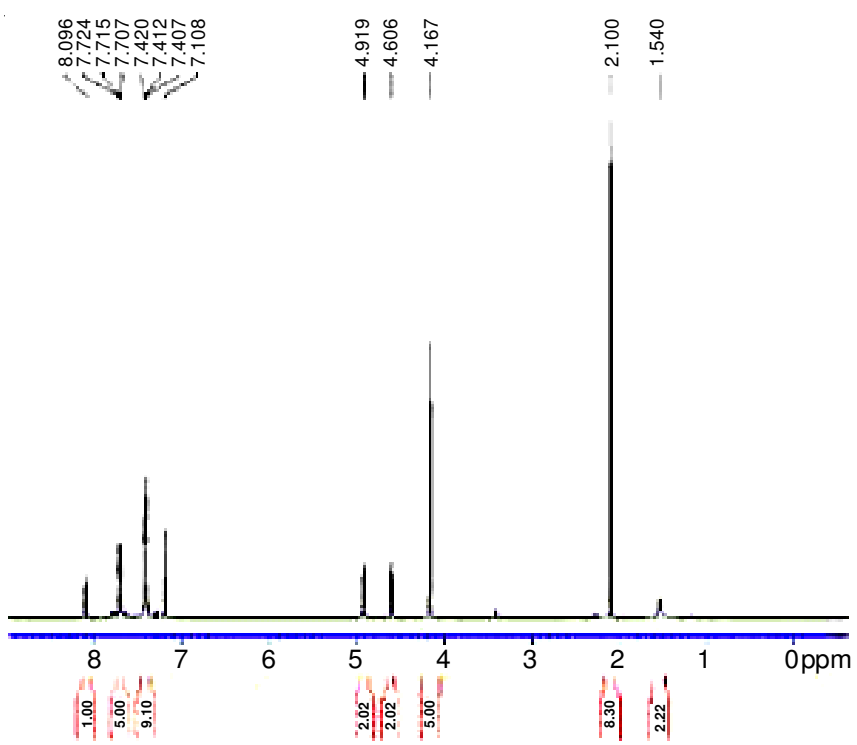

Fig. 1. ${ }^{1} \mathrm{H}$ NMR spectrum of ferrocenylorganostannoxane in $\mathrm{CDCl}_{3}$

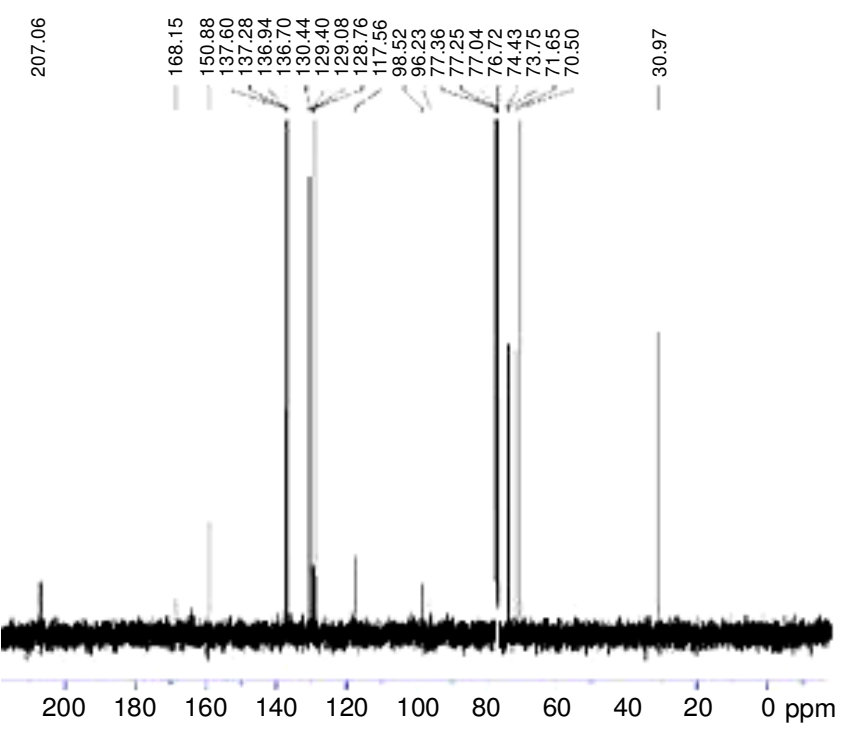

Fig. $2 .{ }^{13} \mathrm{C}$ NMR spectrum of ferrocenylorganostannoxane in $\mathrm{CDCl}_{3}$

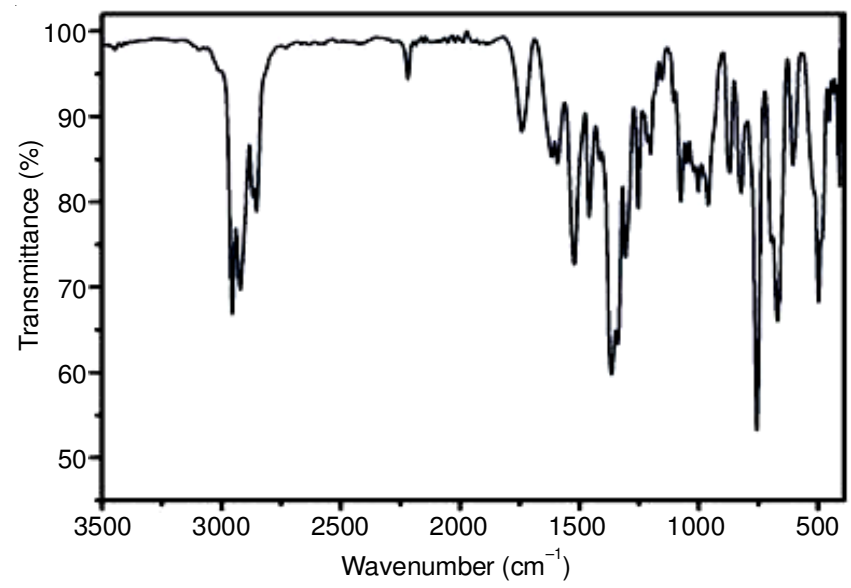

Fig. 3. FT-IR spectrum of ferrocenylorganostannoxane

The UV-visible absorption spectrum of a compound in $\mathrm{CH}_{3} \mathrm{CN}$ $\left(5 \times 10^{-5} \mathrm{M}\right)$ are stable with closely ferrocenyl chromophores in which they disclose two charge-transfer bands. The spectra control a prominent absorption bandwidth a restraint at 264 and $314,380 \mathrm{~nm}$ respectively (Fig. 4), which bounce be deferring a high-energy ligand-centred $\pi-\pi^{*}$ electronic transition. In initiation, a weaker absorption band in the visible region was observed at $515 \mathrm{~nm}$ respectively, which is to be found another localized excitation formed by two roughly degenerated transitions, and $\mathrm{Fe}(\mathrm{II}) d-d$ transition or metal-ligand charge transfer (MLCT) process $[15,16]$.

Fluorescence spectral studies: The fluorescence spectra of compound was investigated at room temperature in $\mathrm{CH}_{3} \mathrm{CN}$ solution. The polymeric structure (Fig. 5) showed broad emission bands indicating charge transfer nature of the transitions. The polymeric structure exhibit one broad emissions at $412 \mathrm{~nm}$ with excitation wavelength value of $314 \mathrm{~nm}$ (Fig. 4). The emission of $412 \mathrm{~nm}$ wavelength is either due to MLCT or LMCT [17]. In addition, emission intensity of much stronger due to increased electronic energy population that take place through polymeric structure in spite of its considerable conjugated $\pi$-electron nature in the system [18]. 


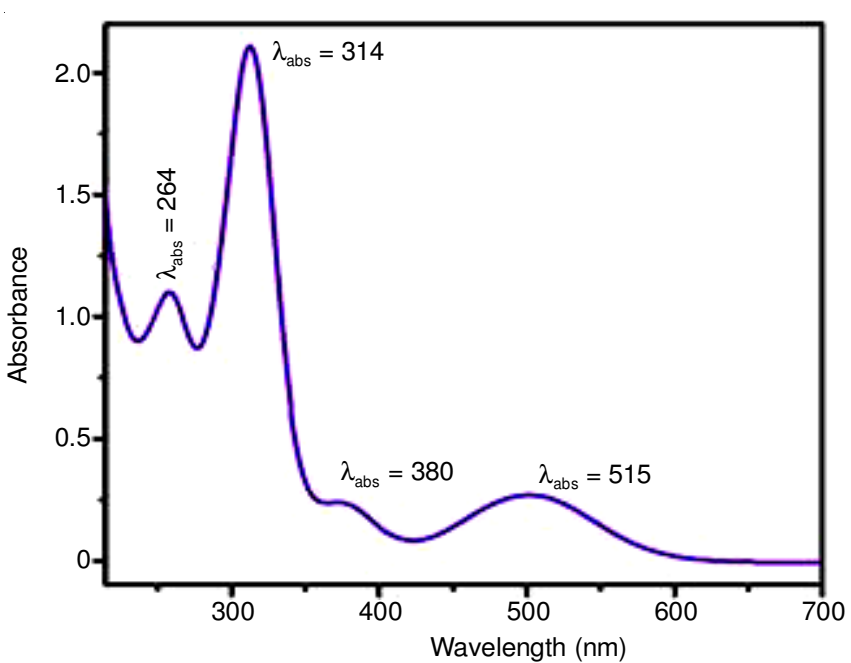

Fig. 4. UV-visible absorption spectrum of ferrocenylorganostannoxane in $\mathrm{CH}_{3} \mathrm{CN}$ solution $\left(5 \times 10^{-5} \mathrm{M}\right)$

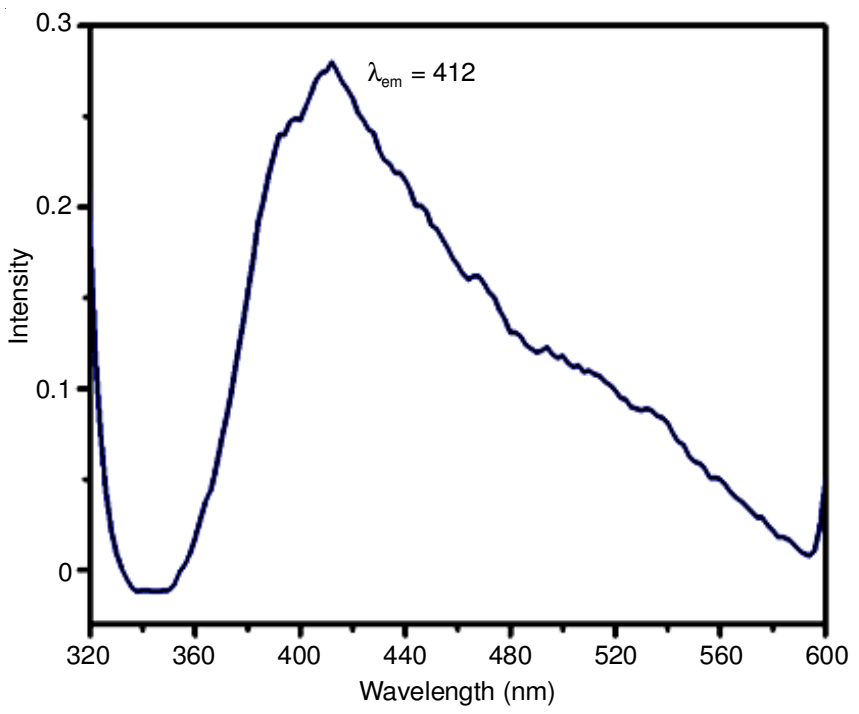

Fig. 5. Fluorescence emission and excitation spectra of ferrocenylorganostannoxane in $\mathrm{CH}_{3} \mathrm{CN}$ solution $\left(5 \times 10^{-5} \mathrm{M}\right)$

Electrochemistry: The redox potential of ferrocene derivatives changes within wider limits. The redox potential depends on the electron-donating or electron withdrawing ability of the substituents. Thus, the redox properties can be rather strongly affected by altering the substituent nature [19]. The redox-potential for ferrocene-ferricenium couple ranges from 0 to $1 \mathrm{~V}$. The single oxidation and reduction was observed with $\mathrm{a}\left[\mathrm{E}_{1 / 2}=\left(\mathrm{E}_{\mathrm{pa}}+\mathrm{E}_{\mathrm{pc}}\right) / 2\right]$, $\mathrm{E}_{1 / 2}=0.65 \mathrm{~V}\left(v s . \mathrm{Ag} / \mathrm{AgCl},\left[\left(n \mathrm{Bu}_{3} \mathrm{SnOC}(\mathrm{O}) \mathrm{CNCHFc}\right)_{\mathrm{n}}\right]\right.$ (Fig. 6). It clearly indicates that the redox potential of polymeric compound is in the range of ferrocene unit and the value is compared with literature compounds as shown in Table-1. The electrochemical property $\left(\mathrm{E}_{1 / 2}\right)$ of molecule mainly depends on the

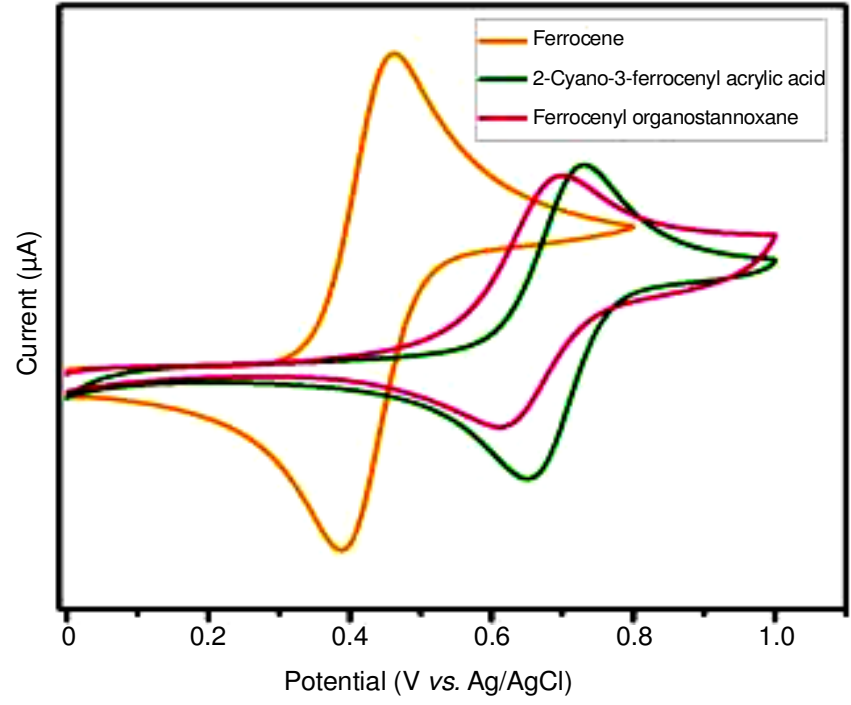

Fig. 6. Cyclic voltammogram obtained to 1-3 in the presence of 0.1 M TBAP in solution $(0.1 \mathrm{~V} / \mathrm{s})$ in $10^{-3} \mathrm{M} \mathrm{CH}_{3} \mathrm{CN}$ solution

substitution, which is suggested that electron withdrawing property of the carboxylate from cyclopentadienyl rings and the coordination bond between carboxylate and $\mathrm{Sn}$ atom, the effectiveness of cyclic voltammetry results from its capability for rapidly observing the redox behaviour over a wide potential range [20].

\section{Conclusion}

The organostannoxane polymer was synthesized based on 2-cyano-3-ferrocenyl acrylic acid. The compound was characterized by FT-IR, ${ }^{1} \mathrm{H}$ and ${ }^{13} \mathrm{C}$ NMR. It is further supported by absorbance spectra shows high-energy ligand-centred $\pi-\pi^{*}$ electronic transition and metal ligand charge transfer. Fluorescence spectra has dominated emission intensity of much stronger due to acceptor group $(-\mathrm{C} \equiv \mathrm{N})$ in the polymeric unit. Electrochemical data that clearly indicate a mutual donor-acceptor electronic influence between the electron releasing to organometallic units. This enhanced donor-acceptor properties of the molecule can be utilized in dye synthesized solar cell (DSSC).

\section{ACKNOWLEDGEMENTS}

The authors thank VIT University for providing 'VIT SEED GRANT' for carrying out this research work. The authors are also grateful to acknowledge SIF-VIT, VIT University, Vellore, India for providing the spectral analysis.

\section{REFERENCES}

1. F. Frehill, K.H.G. Schulte, C.P. Martin, L. Wang, S. Patel, J.A. Purton, J.G. Vos and P. Moriarty, Langmuir, 20, 6421 (2004); https://doi.org/10.1021/la036414y.

2. N. Das, A.M. Arif, P.J. Stang, M. Sieger, B. Sarkar, W. Kaim and J. Fiedler, J. Inorg. Chem., 44, 5798 (2005); https://doi.org/10.1021/ic0481834.

\begin{tabular}{|c|c|c|c|c|c|c|}
\hline \multicolumn{7}{|c|}{$\begin{array}{c}\text { TABLE-1 } \\
\text { ELECTROCHEMICAL DATA FOR COMPOUNDS }\end{array}$} \\
\hline S. No. & Compound & $\mathrm{Ep}_{\mathrm{a}}(\mathrm{V})$ & $\operatorname{Ep}_{c}(\mathrm{~V})$ & $\mathrm{E}_{1 / 2}(\mathrm{~V})$ & $\Delta \mathrm{E}(\mathrm{mV})$ & Ref. \\
\hline 1 & Ferrocene & 0.459 & 0.389 & 0.42 & 70 & [13] \\
\hline 2 & 2-Cyano-3-ferrocenyl acrylic acid & 0.732 & 0.653 & 0.69 & 79 & [9] \\
\hline 3 & {$\left[\left(n \mathrm{Bu}_{3} \mathrm{SnOC}(\mathrm{O}) \mathrm{Fc}\right)_{\mathrm{n}}\right]$} & - & - & 0.57 & 112 & [13] \\
\hline 4 & {$\left[\left(n \mathrm{Bu}_{3} \mathrm{SnOC}(\mathrm{O}) \mathrm{CNCHFc}\right)_{\mathrm{n}}\right]$} & 0.691 & 0.613 & 0.65 & 78 & This work \\
\hline
\end{tabular}


3. V. Chandrasekhar and R. Thirumoorthi, Organometallics, 26, 5415 (2007); https://doi.org/10.1021/om700622r.

4. D. Braga, L. Maini, M. Polito, E. Tagliavini and F. Grepioni, Coord. Chem. Rev., 246, 53 (2003) https://doi.org/10.1016/S0010-8545(03)00108-5.

5. V. Chandrasekhar, J. Goura, K. Gopal, J. Liu and P. Goddard, Polyhedron, 72, 35 (2014); https://doi.org/10.1016/j.poly.2014.01.017.

6. K.A. Williams, A.J. Boydston and C.W. Bielawski, Chem. Soc. Rev., 36 , 729 (2007); https://doi.org/10.1039/B601574N

7. V. Chandrasekhar, S. Nagendran, S. Bansal, M.A. Kozee and D.R. Powell, Angew. Chem. Int. Ed., 39, 1833 (2000); https://doi.org/10.1002/(SICI)1521-3773(20000515)39:10<1833: AID-ANIE1833>3.0.CO;2-3.

8. J.-L. Fillaut, J. Linares and D. Astruc, New J. Chem., 16, 305 (1992).

9. M. Watanabe, Y.J. Chang, P.-T. Chou, A. Staykov, M. Shibahara, K. Sako, T. Ishihara and T.J. Chow, Tetrahedron Lett., 56, 1548 (2015); https://doi.org/10.1016/j.tetlet.2015.02.012.

10. M. Kondo, R. Shinagawa, M. Miyazawa, M.K. Kabir, Y. Irie, T. Horiba, T. Naito, K. Maeda, S. Utsuno and F. Uchida, Dalton Trans., 515 (2003); https://doi.org/10.1039/B210475J.

11. P.A. Chase, R.J.M.K. Gebbink and G. van Koten, J. Organomet. Chem., 689, 4016 (2004); https://doi.org/10.1016/j.jorganchem.2004.07.032.

12. H. Puff, W. Schuh, R. Sievers, W. Wald and R. Zimmer, J. Organomet. Chem., 260, 271 (1984);

https://doi.org/10.1016/S0022-328X(00)99476-2.
13. V. Chandrasekhar, K. Gopal, S. Nagendran, P. Singh, A. Steiner, S. Zacchini and J.F. Bickley, Chem. Eur. J., 11, 5437 (2005); https://doi.org/10.1002/chem.200500316.

14. V. Chandrasekhar and R. Thirumoorthi, Dalton Trans., 39, 2684 (2010); https://doi.org/10.1039/b922044e.

15. J. Beckmann and J. Bolsinger, Organometallics, 26, 3601 (2007); https://doi.org/10.1021/om0700841.

16. L. Cuffe, R.D.A. Hudson, J.F. Gallagher, S. Jennings, C.J. McAdam, R.B.T. Connelly, A.R. Manning, B.H. Robinson and J. Simpson, Organometallics, 24, 2051 (2005); https://doi.org/10.1021/om0492653.

17. K. Senthilkumar, M. Gopalakrishnan and N. Palanisami, Spectrochim. Acta Part A, 148, 156 (2015); https://doi.org/10.1016/j.saa.2015.03.133.

18. A. Béziau, S.A. Baudron and M.W. Hosseini, Dalton Trans., 41, 7227 (2012); https://doi.org/10.1039/c2dt30549f

19. W.-C. Yen, H.-C. Lin, J.-S. Huang, Y.-J. Huang and Y.-L. Chueh, Sci. Adv. Mater., 6, 1 (2014); https://doi.org/10.1166/sam.2014.1674.

20. V. Chandrasekhar, S. Nagendran, S. Bansal, M.A. Kozee and D.R. Powell, Angew. Chem., 112, 1903 (2000); https://doi.org/10.1002/(SICI)1521-3757(20000515)112:10<1903:: AID-ANGE1903>3.0.CO;2-5 